\title{
Prosjektarbeid i barnehagen - mellom bekvemmelighet og medvirkning
}

\author{
Dag Øystein Nome, Anne Karin Vikstøl Olsen, \\ Lisbeth Ljosdal Skreland \& Kristin Severinsen Spieler \\ Universitetet i Agder, Norge
}

\section{SAMMENDRAG}

I denne artikkelen analyseres samtaler fra personalmøter i to barnehager som arbeider prosjektbasert inspirert av Reggio Emilia-pedagogikk. Observasjoner av møter er supplert med intervju med de pedagogiske lederne. Målet med undersøkelsen har vært å studere hvordan personalet snakker sammen om arbeid med prosjekt i møtene og hvordan dette kan ha betydning for barns mulighet for medvirkning. Vi viser hvordan samtalene arter seg gjennom et prosjektforløp. Underveis $\mathrm{i}$ denne prosessen identifiserte vi fire ulike diskurser som på ulike måter legger føringer for barnas medvirkning i arbeidet med prosjektene. Vi har kalt disse for henholdsvis en medvirkningsdiskurs, en undringsdiskurs, en bekvemmelighetsdiskurs og en resultatdiskurs. Vi konkluderer med at høye faglige ambisjoner kombinert med lite møtetid svekker muligheten for barns medvirkning i prosjektarbeid.

Nøkkelord: diskurs; pedagogisk dokumentasjon; personalsamarbeid; Reggio Emilia

Mottatt: September, 2020; Antatt: Mai, 2021; Publisert: August, 2021

\begin{abstract}
Project-based methods in kindergarten - between convenience and participation

This article analyzes observations from staff meetings in two kindergartens that use a Reggio Emilia-inspired project-based approach as a method of working with children. Interviews with the educational leaders supplement these observations. The aim of the study has been to investigate how staff members talk about their projects in meetings, and how this might affect children's opportunity for participation. We describe how conversations evolve through the different phases of a project. During this process, we have identified four different discourses that, in different ways, set premises for how projects evolve and to what extent the children participate in the process. We have labelled these a participatory-discourse, a wonder-discourse, a convenience-discourse, and an outputdiscourse. We conclude that high professional ambitions combined with limited time for meetings weaken the possibility of children's participation in project-work.
\end{abstract}

Keywords: discourse; pedagogical documentation; Reggio Emilia; staff meeting

\footnotetext{
^Korrespondanse: Dag Øystein Nome, e-post: dag.nome@uia.no

(C) 2021 Dag Øystein Nome, Anne Karin Vikstøl Olsen, Lisbeth Ljosdal Skreland \& Kristin Severinsen Spieler. This is an Open Access article distributed under the terms of the Creative Commons Attribution 4.0 International License (https://creativecommons.org/licenses/by-nc/4.0/), allowing third parties to copy and redistribute the material in any medium or format and to remix, transform, and build upon the material for any purpose, even commercially, provided the original work is properly cited and states its license. 


\section{Introduksjon}

Med utgangspunkt i barnekonvensjonen artikkel 12 hvor barn gis rett til å medvirke $\mathrm{i}$ alle forhold som vedrører dem, inneholder rammeplanen for barnehagen krav om at barna skal få «mulighet til aktiv deltagelse i planlegging og vurdering av barnehagens virksomhet» (Kunnskapsdepartementet, 2017, s. 27). Mange barnehager forsøker å løse dette oppdraget ved å arbeide prosjektbasert.

Prosjektbaserte arbeidsmåter har røtter tilbake til Reggio Emilia-pedagogikkens barne- og læringssyn. Det er barnas interesser og initiativ som skal være førende for valg av læringsinnhold og hvordan arbeidet med dette læringsinnholdet utvikles over tid.

Prosjektene drives fram gjennom faglige refleksjoner i en personalgruppe blant annet basert på systematisk bruk av pedagogisk dokumentasjon. Dette er tid- og ressurskrevende prosesser som ofte krever mye møtetid. Samtidig skal hvert enkelt barns ulike behov for omsorg og trygghet ivaretas, med dertil hørende kartlegging og rapportering rettet mot en rekke omkringliggende institusjoner. Dette arbeidet krever også mye møtetid. Personalmøtene i prosjektbaserte barnehager skal med andre ord dekke mange behov. Spørsmålet vi stiller i denne artikkelen er hva barnehagepersonalet snakker om knyttet til prosjektbaserte arbeidsformer på personalmøter, og hvilken betydning det kan ha for barns mulighet til medvirkning.

Utgangspunktet for artikkelen er deltagende observasjoner av planleggingsmøter i to barnehager og intervju med pedagogiske ledere. Vi retter oppmerksomheten mot hva de snakker om i møtene, og vi har analysert materialet med tanke på å finne hvilke argumenter de benytter seg av og hvordan disse kan identifiseres som ulike diskurser. De ulike stadiene i gjennomføringen av et prosjekt er omdreiningspunktet i artikkelen.

\section{Kunnskapsstatus omkring prosjektarbeid i barnehagen}

Flere forskere har fremmet prosjektarbeid som en måte å jobbe med fagområdene på som ivaretar barnehagens helhetlige læringssyn og barns rett til medvirkning (se bl.a. Fennefoss \& Jansen, 2008; T. Jansen, 2008; Melvold, 2020). Prosjektarbeid handler om å være lydhør for barns livs- og erfaringsverdener og la et faglig forløp utvikle seg i nær dialog med dem (Fennefoss \& Jansen, 2008; K. Jansen, 2013). Å være lydhør kan i mange sammenhenger knyttes til pedagogisk dokumentasjon, som innebærer at dokumentasjoner av barnehagens hverdagsliv gjennomgås i personalgruppen som et utgangspunkt for å styrke barns medvirkning (Åberg \& Taguchi, 2006).

Prosjektbasert arbeid i barnehagen blir ofte sporet tilbake til Loris Malaguzzis initiativ til barnehagereformer i Reggio Emilia i Nord Italia på 80- og 90-tallet (Barsotti, 1998). Målet var å basere pedagogikken på en gjensidig meningsskaping mellom kompetente voksne og kompetente barn, med vekt på kunstneriske arbeidsformer i samarbeid med utøvende kunstnere (Carlsen, 2015; Kjær, 2018). Barnesynet som lå til grunn, ble beskrevet slik: 
Both children and adults need to feel active and important - to be rewarded by their own efforts, their own intelligences, their own activity and energy. When a child feels these things are valued, they become a fountain of strength for him. (Malaguzzi, 1994, s. 2)

Dette er utdanning som relasjon, og da menes relasjon både mellom barn, mellom barn og voksne og ikke minst mellom barn, voksne og deres felles omgivelser (Edwards, 1995). Målet var at disse relasjonene skulle lede til at det oppsto innhold og arbeidsmåter som kunne bli til ulike former for korte eller langvarige prosjektarbeid.

Prosjektarbeid kan også knyttes til Vygotskij-inspirerte begrep som kooperativ lcering (Kim \& Darling, 2009) eller lceringsfellesskap (Kilpatrick et al., 2003; Rogoff, 1994). Barna og pedagogene veksler da mellom å være instruerende eller øvende, erfarne eller nybegynnere fra situasjon til situasjon, og asymmetrien som alltid er til stede i et læringsfellesskap, er dynamisk (Rogoff, 1994). Hvem som lytter til hvem i læringsfellesskapet vil variere. Malaguzzi omtaler det som: "a shift in the role of the teacher from an emphasis of teaching to an emphasis on learning» (Malaguzzi, 1994, s. 3).

En forutsetning for at slike rollebytter skal kunne skje, er at pedagogene sammen med barna og andre deltagere i og rundt barnehagen systematisk reflekterer over ulike former for dokumentasjon fra barnehagens hverdagsliv (Hewett, 2001; Kim \& Darling, 2009; Schroeder-Yu, 2008).

Reggio Emilia-ideene har satt barneperspektivet i sentrum (Dahlberg et al., 1999) og inspirert mange typer pedagogisk praksis (Carlsen, 2015; Eneflo, 2014; Kjær, 2018; Rinaldi, 2006; Vakil et al., 2003). Et kjent utslag av dette er begrepet lyttende pedagogikk (Taguchi, 2000; Åberg \& Taguchi, 2006). I lyttende pedagogikk er det personalets refleksjoner omkring observasjoner av barns ytringer som danner utgangspunktet for at prosjekter oppstår.

Inspirert av Jacques Derrida tar Ann Åberg og Hillevi Lenz Taguchi (2006) til orde for dekonstruerende samtaler i personalgruppen. I møtet med en praksisfortelling er ikke målet å oppnå konsensus, en enighet om hva som skjer og hvorfor. Målet er å legge ulike og motstridende forståelser side om side på bordet som like gyldige i kraft av at de utgår fra ulike diskurser. Hensikten med dekonstruerende samtaler er å komme bakenfor det personalet tror de vet om barnas interesser eller ytringer, for å få øye på mulige forståelser de ikke hadde forventet. Det er de rådende diskursene i personalgruppa som blir dekonstruert. Med diskurs i denne sammenheng menes hvilken barnehagefaglig virkelighet personalet skaper i måten de snakker sammen om barnas ytringer på.

Blant barnehagepersonalet som snakker sammen om livet i barnegruppene vil ulike diskurser dukke opp, for eksempel en utviklingspsykologisk diskurs eller en læringsdiskurs (Åberg \& Taguchi, 2006). En utviklingspsykologisk diskurs vil fortelle historien om hva vi kan forvente at barn er modne for, og det barn uttrykker må tolkes i lys av deres modenhetsmessige mangler. En læringsdiskurs vil fortelle historien om 
hva barna trenger å tilegne seg av kunnskaper og ferdigheter, og de samme ytringene må tolkes i lys av deres forventede motivasjon for å strekke seg mot nye læringsmål. Disse to diskursene vil kunne trekke praksisutøvelsen i ulike retninger.

Det finnes forskning på hvorvidt prosjektarbeid faktisk fremmer barns medvirkning. Mari Pettersvold (2012) undersøkte et prosjektarbeid om bærekraft for å se i hvilken grad arbeidsformen bidro til barns demokratiske deltagelse i barnehagen. Ved hjelp av Jürgen Habermas' teori om kommunikative handlinger fikk hun fram at samtalene mellom barna og barnehagelærerne ikke bar preg av å overbevise eller formidle, men at tvilen og usikkerheten fikk råde. Hun viser blant annet hvordan ordet «kanskje» preget dialogen og dermed drev prosjektet videre gjennom begge parters oppriktige undring. Pettersvold knyttet dessuten an til Basil Bernsteins distinksjon mellom en sterk eller svak innramming og klassifisering av undervisningen. Hun hevder at prosjektarbeidet hun undersøkte bar preg av en svak klassifisering og innramming siden barnehagelærerne bare delvis hadde kontroll over hva som skulle oppstå i prosjektets gang.

Det er også gjort noe forskning på hva som skjer på innsiden av en personalgruppes arbeid med pedagogisk dokumentasjon før, under og etter det daglige arbeidet med barna. Elisabeth Lindgren Eneflo (2014) finner i sin ph.d. at pedagoger kan utvikle prestasjonsangst $\mathrm{i}$ arbeidet med pedagogisk dokumentasjon siden forventningen til bestemte strukturer og prosedyrer er så høye. Hun argumenterer for at disse prosessene bør være fleksible og tilpasset personalgruppens behov. Det er dette sporet vi forfølger videre i dette prosjektet, men i motsetning til Lindgren Eneflo, som primært intervjuet barnehagelærere, har vi observasjoner av personalmøter som den primære datakilden $\mathrm{i}$ jakten på hva personalet snakker om i sine ulike former for prosjektbaserte arbeidsmåter.

\section{Metode}

Undersøkelsen er en små-skala etnografisk undersøkelse basert på deltagende observasjoner av personalmøter i to kommunale barnehager. I etterkant av personalmøtene ble det gjennomført intervju med de pedagogiske ledere som var ansvarlig for møtene. Etnografi har et overordnet mål om å beskrive, analysere og tolke kulturelle handlingsmønstre, oppfatninger og språk i en gruppe mennesker (Creswell, 2008; Postholm, 2010) og kan derfor innebære flere ulike datakilder, som deltagende observasjon og kvalitative intervju (Crang \& Cook, 2007; Fangen, 2010; Lofland \& Lofland, 1995). Med hensyn til forskningsspørsmålet vi har stilt, er observasjonene av møtene den primære datakilden, med intervjuene som kilde til utfyllende beskrivelser av personalets arbeid.

\section{Deltagere og rekruttering}

De to barnehagene var kommunale fra to kommuner i Sør-Norge. Medlemmene i forskergruppen arbeider med barnehagelærerutdanningen, og barnehagene ble 
rekruttert blant institusjonens praksisbarnehager. Vi har valgt å referere til barnehagene som Solstua og Elvebakken.

Begge barnehagene profilerer seg som prosjektbarnehager. Solstua har en klar føring $\mathrm{i}$ årsplanen om at prosjektarbeid skal danne grunnlaget for barnehagens faglige innhold. Beskrivelsene i årsplanen av de ulike fasene i et prosjekt er grundige, og henvisninger til at de samarbeider med lokale kunstnere gjør at barnehagen framstår som Reggio Emilia-inspirert, uten at dette sies eksplisitt. En modell av prosjektprosessen som er gjengitt i årsplanen, lå laminert på bordet foran oss under møtene. Elvebakken beskriver også prosjekt som en sentral arbeidsmåte i årsplanen, men prosessen er ikke like inngående beskrevet som i Solstuas årsplan. Det er heller ikke her noen henvisninger til Reggio Emilia eller andre inspirasjonskilder.

\section{Datainnsamlingen}

Vi deltok på to til fire møter i hver barnehage over en to-måneders-periode. Møtene hadde noe ulik karakter, men de fleste var møter i personalgruppene tilknyttet én avdeling. Det deltok fire til fem personer med ulike oppgaver og med ulik profesjonsbakgrunn: barnehagelærere, fagarbeidere og ufaglærte assistenter.

Vi var to forskere til stede på hvert møte, og vi satt rundt møtebordet sammen med personalgruppene. På det første møtet introduserte vi oss og gjorde oss kjent med arbeidsmåtene i personalgruppen. De første observasjonene ble gjennomført uten lydopptak, for å bygge opp en trygghet i gruppa i det å ha forskere til stede (Postholm, 2010). Fra det andre møtet giorde vi lydopptak.

Vi valgte å se på oss selv som deltagende observatører, selv om det varierte i hvor stor grad vi faktisk deltok i samtalene. Vi kunne stille spørsmål ved behov, og personalgruppen kunne også henvende seg til oss for å forklare kontekst omkring noen av diskusjonene, men vi deltok ikke i replikkvekslingene som ledet til identifiseringen av de ulike diskursene. Observasjonene innebar med andre ord både et innenfra- og et utenfra-blikk på samtalene (Fangen, 2010).

I etterkant av møtene gjennomførte vi intervjuer med de pedagogiske lederne som var ansvarlige for møtene (Lofland \& Lofland, 1995). Vi valgte å gjennomføre ett intervju i hver barnehage, siden dette viste seg å være tilstrekkelig med hensyn til å få en god nok utfyllende forståelse. Intervjuguiden var innrettet med tanke på å få et overblikk over barnehagens arbeidsform, planleggings- og dokumentasjonspraksis ut over det observasjonene ga innsikt i. Noe tid ble også brukt til å reflektere sammen med barnehagelæreren omkring innholdet i de enkelte møtene.

Forskerteamet arbeider som nevnt i barnehagelærerutdanningen og hadde derfor en viss kjennskap til barnehagene og møtedeltagerne fra før av, siden enkelte av dem også arbeider som praksislærere. Dette kunne innebære en viss forutinntatthet fra vår side, og en fare for å påvirke personalets samtaler i større grad enn om vi ikke hadde noen forutgående relasjoner med dem. Forskereffekten ble reflektert i analysearbeidet (Postholm, 2010). Vi fant at den allerede eksisterende relasjonen bidro til at deltagerne slapp oss inn i gruppene, og relasjonen med utdanningsstedet styrket 
motivasjonen for å delta. Allikevel må vi ta høyde for at deltagerne kunne ha en viss interesse av å vise seg fra sin beste side av hensyn til forventningene til rollen som praksislærere og praksisbarnehager.

\section{Bearbeiding og analyse}

Lydloggene fra møtene ble transkribert, og med støtte fra feltnotater og intervju kunne vi starte arbeidet med å analysere materialet. Analysen er en identifisering av hvilke argumenter personalet tok i bruk når de snakket sammen om prosjektarbeid, og hvilke diskurser de ulike argumentene er uttrykk for. Med diskurs i denne sammenheng menes det Fairclough (2008, s. 18) beskriver som: «en praksis som ikke bare repræsenterer verden, men også giver verden betydning, konstituerer den og konstruerer den i mening». En slik diskursforståelse ligger til grunn for analysen av vårt datamateriale. Dette er i tråd med hvordan diskursanalyse er beskrevet i metodelitteratur for små-skala forskning på sosiale fenomen, forklart av Denscombe (2007, s. 308) som: "to unpack the text or image in order to reveal what people are trying to do through the talk, text or image».

Vi har riktignok ikke lagt til grunn at personalet valgte å ta $i$ bruk bestemte diskurser med en intensjon om å etablere en bestemt sosial virkelighet, men at utsagn likevel kan tolkes inn i en diskursiv ramme. Det vil si at informantenes utsagn kan skape en bestemt sosial virkelighet uten at det er intendert, og at det er mulig gjennom analysen å kategorisere dette som ulike og ofte konkurrerende diskurser.

\section{Etiske overveielser}

Informantene ble først gitt skriftlig informasjon om forskningsprosjektets innhold og målsetting, beskyttelse av anonymitet, gjennomføringsplan og deres generelle rettigheter som informanter. Skriftlig samtykke fra deltagerne ble deretter hentet inn. Foreldrene har også samtykket, siden deltagerne måtte ha anledning til å snakke om enkeltbarn i møtene vi observerte. Det er brukt fiktive navn i analysearbeidet og navn er utelatt i artikkelen. Prosjektet ble registrert og godkjent av Norsk senter for forskningsdata (NSD).

\section{Resultat og diskusjon}

Vi har valgt å organisere materialet etter hvordan samtalene beskriver framdriften i ulike prosjektarbeid, fra barnas lek fanger personalets oppmerksomhet, via oppstart og gjennomføring av prosjekt, og til det avsluttes. Underveis drøfter vi hvilke ulike diskurser som gjør seg gjeldende i de dilemma og utfordringer personalet setter ord på.

\section{$\AA$ finne spor av barns interesser}

Barnehagene vi undersøkte startet året uten en plan for innholdet, og det medførte at de første ukene gikk med til å finne innholdet gjennom å se og lytte til 
barna. Pedagogen i Solstua sa at: «Alle er liksom litt ekstra oppmerksom på hva ungene er opptatt av [...] hva er det de leker». Barnas interesser ble fanget opp og bearbeidet på ulike måter. Pedagogen i Elvebakken beskrev denne prosessen som «snakk i gangene», og at dette etter hvert blir formet til et tema på et av møtene i personalgruppa. I utgangspunktet benyttet pedagogen her det vi vil kalle en medvirkningsdiskurs. Det er barns perspektiv de omtalte som det vesentligste å få tak i, og de var opptatt av at det skulle være et stort, åpent rom i planene med plass til barns initiativ.

Det var tydelig at personalgruppene kunne være litt drevet av hva de forventet skulle dukke opp som barns interesser. «Vi fanger opp for eksempel Kaptein Sabeltann, mest sannsynlig. Kanskje mange har vært på den nå i sommer», sa pedagogene i Solstua og fortsatte: «Det er liksom veldig fint for oss. Okay, det kan vi, det er veldig lett for oss å gjøre». Solstua hadde utstyr til sjørøvertema liggende klar på lageret. Denne måten å snakke på kan kalles en bekvemmelighetsdiskurs. Personalgruppene fanget opp det som var lettest og mest praktisk. I denne barnehagen førte bekvemmelighetsdiskursen til at oppstarten ofte endte med sjørøver som innhold. Dette ville kunne bety at noen typer uttrykk og kan hende også noen barns uttrykk, ble lagt merke til i større grad enn andre, og da fortrinnsvis de stemmene som bekreftet det personalgruppa forventet og kanskje også ønsket.

På ett av personalmøtene i Elvebakken ble det stilt spørsmål om jentene også var interessert i det tema som hadde utkrystallisert seg. Det kan tyde på at de erfarte at guttenes interesser lettere ble fanget opp enn jentenes. Blant temaene informantene snakket om var flere av dem maskulint preget, som lastebiler og hai i tillegg til sjørøvere.

Det er grunn til å diskutere om en bekvemmelighetsdiskurs kan gjøre at de høyrøstede ideene ofte får gjennomslag, siden det er mer bekvemt å spille videre på sterke uttrykk fra barna enn de mer subtile. De sterke uttrykkene vil uansett være til stede i gruppen, og det er kan hende mer bekvemt å spille på lag med de sterke uttrykkene enn å ha dem som bakgrunnsstøy i arbeidet med å løfte fram andre tema. Pedagogen i Solstua, hvor de forventet Kaptein Sabeltann hver høst, satte ord på dette:

Også kan det jo være guttene og jentene i hjørnet som er veldig opptatt av insekter for eksempel og skrek bare ikke så høyt, men er veldig engasjert. Og likevel er det jo synlig på en måte, men det er ikke så lett å få øye på det, enn den svære «hiv og hoi", og det er kanskje noe voksne synes er veldig gøy. Det er veldig lett for oss å bli engasjert av dette selv.

Dekonstruerende samtaler blant personalet kunne kanskje avdekket hvordan bekvemmelighetsdiskursen og medvirkningsdiskursen var i spill når prosjekt-tema skulle velges. Møtene vi deltok på var preget av høyt tidspress og mange krevende enkeltsaker omkring barna. Vi så i liten grad at det var rom for å foreta en analyse av hvilke diskurser de snakket ut fra, og motsetningene mellom diskursene ble ikke 
satt ord på. Tema for prosjektene, som altså ble barnehagenes faglige innhold, kunne derfor oppstå på bakgrunn av vaner.

\section{Pangstart - å sette et prosjekt i gang}

«Pangstart» var et ord brukt av informantene, og med dette pekte de på at et prosjektarbeid skulle ha en tydelig markert oppstart. En pangstart besto gjerne av å overraske barna ved å forandre på interiøret eller tilføre nytt materiell fra en dag til en annen. Pedagogen i Solstua fortalte om oppstarten av et sykehusprosjekt:

Da kom de en morgen inn til temarommet, og da er alt gjort klart til sykehusrom. Da har vi hengt opp masse sånne bilder og der var et operasjonsbord. Vi hadde fått tak i sånne hetter, sprøyter, bandasjer. Det blir veldig sånn: «øy, her var det masse nytt». Ja det blir en pangstart rett og slett.

I Elvebakken skulle de har reise som tema og ville lage en magisk koffert til åpningen av prosjektet. «Magisk» var et nøkkelord for denne personalgruppen: «Jeg synes ikke det skal være for mye ideer [...] vi skal skape undring», uttrykte pedagogen på møtet hvor prosjektet ble planlagt. Samtalen i personalgruppa var begynt å ta litt av med mange gode ideer, da pedagogen kom med denne påminnelsen.

Når personalgruppene snakket om å overraske, forbause eller forbløffe barna fra en dag til den neste, benyttet de seg av det vi vil kalle en undringsdiskurs. Det samme gjelder uttrykk som å skape magi. Planleggingen av pangstarten bar preg av fri idemyldring i personalgruppen som av og til måtte bremses. Ønsket om at pangstarten skulle skape undring ble i samtalene forbundet med å holde et rom åpent for barna, og for stor iver etter å fylle på med gode ideer i oppstartsfasen ble omtalt som å lukke rommet for undring. I møtene vi observerte kunne det virke som om det var pedagogene som satte på bremsene når ideene tok overhånd, og som minnet om å gi rom for barns medvirkning og undring.

Bernsteins begreper sterk eller svak innramming og klassifisering av innhold og arbeidsmåter kan være relevant her. En undringsdiskurs skaper en svak innramming og klassifisering fordi mange muligheter blir holdt åpne med et ord som «magisk», slik ordet «kanskje» dominerte samtalen mellom barn og personale i Pettersvolds undersøkelse (2012).

Pangstarten kunne likevel lett bli tilrettelegging av innholdet på personalets premisser, og det dukket opp høye ambisjoner hos enkelte av de ansatte i samtalene. Vi har valgt å kalle dette en resultatdiskurs. Den viste seg i hvordan personalet snakket sammen om sine forventninger til hva som skal lages av synlige produkter i prosjektet. Frykten for at det skulle gå for lang tid utover høsten før barnehagen fikk et definert innhold og frykten for at prosjektet skulle renne ut i sanden og ikke ta skikkelig av, var også et uttrykk for en resultatdiskurs. Resultatdiskursen så ut til å skape en risiko for nederlag, av å ikke strekke til, ikke være faglig nok, og ikke kunne vise barnehagen fra $\sin$ beste side. I den neste fasen av prosjektarbeidet gjorde derfor denne diskursen seg enda mer gjeldende. 


\section{«Triggere» som holder interessen ved like}

Det oppsto som nevnt fort en frykt for at et prosjekt ikke skulle ta tilstrekkelig av. Personalet snakket i den forbindelse om "triggere» som skulle holde prosjektet varmt. «Vi må være flinke til å fylle på underveis etterhvert som interessen dabber av. Hjelpe det til å ta den veien vi vil», sa en av pedagogene i Elvebakken. Det var med andre ord en bekymring til stede i personalgruppen for at interessen kunne «dabbe av».

Andre informanter hadde en lignende bekymring. En av dem brukte betegnelsen "å legge ut spor» om arbeidet for å holde interessen ved like, og «fylle på underveis». Et annet uttrykk som ble brukt var «å hive bensin på bålet» og «å lage litt action». Disse formuleringene antyder at personalet har en ambisjon med prosjektet. At prosjektet skulle «ta den veien vi vil», indikerer dette.

Disse utsagnene representerer også en resultatdiskurs. Personalet fikk fort store tanker om hva som skulle skje underveis og hvor de skulle ende opp. Det kunne dreie seg om rent faglige ting de håpte å oppnå, for eksempel å nå prosessmålene i rammeplanen, men det kunne også dreie seg om mer synlige markører av godt gjennomført arbeid. Her er et eksempel på det siste fra en samtale i Elvebakken:

\footnotetext{
Pedagogisk leder: Det kan jo være fint å lage noe som vi henger opp på veggen, som pynter. Altså vi kan jo gjøre det veldig enkelt.

Fagarbeider: Noe med høstfarger, blader som de skal laminere for eksempel.

Fagarbeider 2: Lønnebladene for eksempel. De er skjønne. Hva er det nå de blir for noe - ja lage ansikt på de.

Fagarbeider 3: Ja, det blir jo rev. Du kan lime på noen øyer på de.

Pedagogisk leder: Bare det er noe som ungene kan lage selv, er det det samme hva det er for noe sånn sett.
}

Som denne dialogen viser, var ambisjonen om å lage noe fint viktig. Likevel var det, som nevnt tidligere, ofte pedagogen som tok jobben med å bringe barns behov og dermed medvirkningsdiskursen inn i samtalen. Pedagogen utdypet dette i intervjuet på denne måten: «Jeg må gjerne stoppe noen ting som de har lyst til [...] Når de skal lage ting, så har de litt høye forventninger til hva som skal produseres.» Her var pedagogens perspektiv å gjøre det enkelt og å giøre noe barna kunne få til selv. Her måtte kanskje også undringsdiskursen vike for medvirkningsdiskursen. Pedagogen hadde en målsetting om å gi barna råderett over situasjonen.

\section{Å avslutte på en god måte}

Som sagt uttrykte informantene ofte store ambisjoner om lengden på prosjektene, at de stadig utviklet seg fram mot en slags finale, gjerne etter et par måneders forløp. Denne forventningen ble fort preget av en resultatdiskurs og kunne framstå som voksenstyrt. Det er lett å forstå at personalet hadde behov for å skape en innramming av det pedagogiske arbeidet med at et prosjekt hadde en definert begynnelse og en definert slutt. Barns dynamiske lek beveger seg ikke alltid lineært mot en finale før noe nytt kan oppstå. Dette var pedagogene oppmerksomme på, og i Solstua hadde et 
sykehusprosjekt gradvis og umerkelig gått over til å handle om graviditet og fødsler basert på at det var den veien barnas oppmerksomhet gikk. Pedagogen beskrev det slik:

Også har vi den gjengen som er glad i å føde. Det er jo mye aktivitet der ennå. Og vi sa ikke til dem at de må stoppe [...]. Det er jo vanlig barnelek, og de kan jo leke sykehus selv om det ikke er et prosjekt. Så jeg har ikke følt at de slutter å leke en type lek fordi noen har sagt det. Det er bare at de voksne ikke bevisst setter seg ned for å stimulere den type leken da. Sånn som jeg opplever det da.

Her lot pedagogen medvirkningsdiskursen prege situasjonen. Barna hadde tatt over hele prosjektet og drev det videre uten hjelp fra personalet. Barnas interesse for graviditet og fødsler ga personalet i denne barnehagen ideen om et nytt prosjekt som skulle omhandle det å legge egg. De hadde fått tak en rugekasse og befruktede hønseegg, og de skulle klekke ut rumpetroll. Utklekkingen gikk ikke etter planen, noe som medførte denne korte replikkvekslingen på det påfølgende møtet:

Pedagogisk leder: Hvor gjorde dere av ... fostrene?

Fagarbeider 1: De gikk i matavfallet

Fagarbeider 2: Da har vi hatt litt om kildesortering også! [latter rundt bordet]

Den siste humoristiske kommentaren var tilsynelatende en mild harselering over forventningen om at prosjektet skulle kunne forankres faglig i fagområdenes prosessmål altså resultatdiskursen. Selv om personalgruppene kunne vise en del selvironi med tanke på hvilke faglige mål som kunne nås, lå det også et alvor over dette arbeidet. Det var viktig for dem i ettertid å vise at arbeidet hadde hatt en forbindelse med rammeplanen.

Barnehagene som arbeider på denne måten, har sluttet å lage halvårsplaner. Planene erstattes av grundige halvårsrapporter, og i Solstua ble møtene vi deltok på brukt til planleggingen av denne rapportskrivingen. Halvårsrapporten skulle vise hva som faktisk hadde skjedd og ikke minst hvordan de så at rammeplanens mål hadde blitt arbeidet med. Dette ble i møtene omtalt som «å dobbeltsjekke» i ettertid at de har vært innom det de skal ha vært innom. Det var tydelig at denne rapportskrivingen hadde foreldre som en sentral mottager. Det kan stilles spørsmål ved om slike rapporter først og fremst er egnet for å vise utad at de hadde vært faglige nok, og at de i mindre grad egner seg til internt bruk for å lytte til barna og videreutvikle den pedagogiske virksomheten. Mye tyder på at medvirkningsdiskursen og undringsdiskursen står sterkt i oppstarten og gjerne er synliggjort i årsplanen, men mye tyder også på at resultatdiskursen blir tydeligere mot slutten av barnehageåret.

\section{Avsluttende drøfting av de ulike diskursene}

Vårt datamateriale retter søkelyset mot flere interessante utfordringer og dilemma med å arbeide prosjektbasert. Prosjektarbeid slik det er forankret i Reggio 
Emilia-pedagogikk (Barsotti, 1998) og i lyttende pedagogikk (Åberg \& Taguchi, 2006), er uløselig knyttet til en medvirkningsdiskurs. Siden estetiske og kunstneriske praksiser er betonet, er også undringsdiskursen sentral (Kjær, 2018). Det gjelder å skape magi i barnehagen, og det gjelder å starte utsagnene med "kanskje» for å beholde et åpent mulighetsrom for barna (Pettersvold, 2012).

Medvirkningsdiskursen vi fant handlet om å gi rom for barnas initiativ, ofte med en intensjon om å gjøre ting på barnas premisser. Undringsdiskursen handlet mer om de voksnes initiativ og ideer, men med oppmerksomheten rettet mot å vekke barnas følelser, sette i gang fantasien og skape magi. Vi fant at bruken av disse to diskursene preget personalgruppenes visjoner om hvordan prosjektene skulle bli. Prosjektene starter gjerne med å lytte til barnas stemme gjennom å observere leken deres og la observasjonene være gjenstand for refleksjoner i personalgruppen (Åberg \& Taguchi, 2006). Vår undersøkelse viser at det er åpenbare utfordringer med å lytte seg fram til et prosjekt-tema giennom observasjon av barns lek. Refleksjonsprosesser, for eksempel gjennom dekonstruerende samtaler (Åberg \& Taguchi, 2006), krever god tid. Konsekvensene av å bruke for liten tid kan være mange: Er det alltid barnas stemmer personalet lytter til, og blir alle lyttet til like godt? Som vi har vist, virker pedagogene bevisst på at det kan være ubalanse $\mathrm{i}$ om det er guttenes eller jentenes stemme som blir hørt best. Dessuten er det noe med lydstyrken og synligheten i barnas uttrykk som gjør det bekvemt å velge noe framfor noe annet.

Det er en fare for at personalet lytter etter det samme som de kunne høre i fjor og året før der igjen, som personalet som forventet sjørøvertema hver høst. Denne forventningen henger også sammen med hva barnehagen har gode tradisjoner med, hva de har materiell og utstyr til, og hva personalet er kompetent og komfortable med.Vi har kalt dette en bekvemmelighetsdiskurs.

Det er lett å forstå at en slik diskurs gjør seg gjeldende. Vi observerte en åpenbar konflikt mellom ambisjonene om store prosjekter og omsorgsarbeidet, tilretteleggingen for enkeltbarns behov og hverdagens mange praktiske giøremål.Våre informanter synes å ha lite tid til rådighet for å snakke faglig sammen. Vi vil anslå at bortimot 80 prosent av tiden på møtene vi observerte gikk med til helt nødvendige samtaler om enkeltbarn og diverse praktiske kabaler. 20 prosent av tiden gjensto da til å evaluere framdriften av prosjektarbeidene eller å systematisk arbeide med pedagogisk dokumentasjon. Det er naturlig at bekvemmelighetsdiskurser om hva de pleier å giøre, hva som har fungert fint og hva de har kompetanse og utstyr for liggende på lageret, lett får gjennomslag på bekostning av medvirknings- og undringsdiskursen.

En annen utfordring vi har belyst er at det fort oppstår det vi har kalt en resultatdiskurs. Som flere av våre informanter har vist, er det en utfordring å holde personalets ambisjoner i tømme. De vil så mye og har en idemyldring som av og til giør det nødvendig for pedagogene å tråkke på bremsen og minne om barneperspektivet. Prosjektene kan fort få en voksen dramaturgi.

Mens barnas lekemønster har en uberegnelig flyt og et retningsløst hit-og-dit-preg, er prosjektene ofte lineære med en stigende kurve fram mot en finale som gjerne 
skal synes og høres utenfor barnehagens vegger. Det kan være i form av en bok, en utstilling eller en fest, og ofte med foreldre som en viktig målgruppe. Det er relevant å spørre hvem prosjektene er til for. Det skal helst gå «den veien vi vil», som det ble uttrykt i et av møtene vi observerte. Et prosjekt som ikke tok av og som rant ut i sanden kunne bli forbundet med et faglig nederlag, og dermed en følelse av å ikke lykkes som profesjonsutøver. Det virket også som om informantene kunne vise frykt for å framstå som faglig uvirksomme hvis prosjektet ikke tok av.

Det er verd å merke seg at informantene evnet å se forbi dette presset. Her er pedagogen i Solstuas refleksjon om tiden etter at kyllingene døde og et insektprosjekt hadde rent ut i sanden:

Ja, så vi hadde det veldig fint sånn mot slutten av barnehageåret og ungene hadde det bra, og vi var opptatt av insekter. Vi brukte mye tid på det. Men det var godt å ikke sette et navn på det, at vi hadde et prosjekt om insekter.

Merkelappen prosjektarbeid kan tidvis se ut til å være belastende, kanskje fordi det fort knyttes til en resultatdiskurs som skaper høye forventninger til egne prestasjoner. Et prosjektarbeid preget av en levende medvirkningsdiskurs krever mye tid til felles refleksjoner, og ofte mye videre rammer rundt personalets møtetid enn det er ressurser til. Resultatet blir lett at bekvemmelighetshensyn vinner fordi det er den letteste veien til et synlig resultat når tiden til å snakke faglig sammen er knapp.

Prosjektbaserte arbeidsmåter blir dermed ikke uten videre en måte å innfri rammeplanens krav om å gi barn «mulighet til aktiv deltagelse i planlegging og vurdering av barnehagens virksomhet» (Kunnskapsdepartementet, 2017, s. 27). Informantens beskrivelse av å senke ambisjonene, at de kunne dele interessen for insekter med barna uten at det fikk merkelappen «prosjekt», er i så måte interessant. Muligens opplevde barna større rom for medvirkning og undring her enn i et ambisiøst prosjektarbeid det ikke var gode nok rammer til.

\section{Konklusjon}

Måten barnehagepersonalet snakker sammen om arbeidet sitt på, i dette tilfellet prosjektarbeid, vil prege hvordan arbeidet med barna forløper. Vi har identifisert fire ulike diskurser om prosjektarbeid som er i spill i personalets samtaler: en medvirkningsdiskurs, en undringsdiskurs, en bekvemmelighetsdiskurs og en resultatdiskurs. Alle de ulike diskursene vil trolig være i bruk samtidig i planlegging og gjennomføring av et prosjektarbeid. Medvirkningsdiskursen og undringsdiskursen er i tråd med intensjonene med prosjektbaserte arbeidsformer, og preger gjerne oppstartsfasen av prosjektene. Men vi har vist at høyt tidspress og mange praktiske hensyn fremmer en sterk bekvemmelighetsdiskurs og høye forventninger om synlige resultat fremmer en like sterk resultatdiskurs. Det er dermed ikke gitt at prosjektbaserte arbeidsmåter styrker barnas mulighet for medvirkning i barnehagen. Jo høyere ambisjonsnivået er, 
jo mindre synes muligheten for reell medvirkning å være, med mindre rammene for personalets møtetid gjøres romslige nok.

\section{Forfatteromtale}

Dag Øystein Nome arbeider som førsteamanuensis i pedagogikk ved Universitetet i Agder og som førsteamanuensis 2 ved Steinerhøyskolen. De senere årene har han skrevet artikler og bokkapitler om lek, danning, barndom og barnehage. Hans doktorgrad fra 2017 omhandler barn-barn-relasjoner i lek i småbarnsavdelinger. Nomes seneste publikasjoner er boka Hverdagshendelsenes pedagogikk og Toddlers as ignorant citizens i Contemporary Issues in Early Childhood.

Anne Karin Vikstøl Olsen er universitetslektor ved Institutt for pedagogikk ved Universitetet i Agder. Hun underviser i barnehagelærerutdanningen, og hennes forskningsfelt er didaktikk og utdanningsforskning med fokus på studenters identitet- og mestringstro. Hun er i tillegg leder av Profund - et prosjekt for undervisning på tvers av profesjonsutdanningene ved UiA. Hennes seneste publisering er The role of individual processes and learning environment in the prediction of grades in a sample of Norwegian students i Cogent Education (Olsen, Spieler \& Kovac, 2018).

Lisbeth Ljosdal Skreland er førsteamanuensis ved Institutt for pedagogikk ved Universitetet i Agder. Hun har vært opptatt av barnehagelærere i sine arbeider, og hennes doktorgrad fra 2016 omhandlet regler og verdier i barnehagelærerens yrkesutøvelse. Hun er også opptatt av migrasjonsspørsmål og tema knyttet til flyktningbarns møte med barnehager. Boka Regler $i$ barnehagen er blant hennes seneste publikasjoner.

Kristin Severinsen Spieler arbeider som assisterende instituttleder og universitetslektor i pedagogikk ved Universitetet i Agder. Hun underviser i barnehagelærerutdanningen, og har vitenskapelige publikasjoner om kunnskapsdeling og profesjonsidentitet, blant annet The role of individual processes and learning environment in the prediction of grades in a sample of Norwegian students i Cogent Education (Olsen, Spieler \& Kovac, 2018).

\section{Kilder}

Barsotti, A. (1998). Skapende kommunikasjon i Reggio Emilia. Pedagogisk forum.

Carlsen, K. (2015). Forming $i$ barnehagen $i$ lys av Reggio Emilias atelierkultur [Doktorgradsavhandling, Åbo Akademi University]. Doria. http://urn.fi/URN:ISBN:978-951-765-783-9

Crang, M. \& Cook, I. (2007). Doing ethnographies. Sage.

Creswell, J. W. (2008). Educational research: Planning, conducting, and evaluating quantitative and qualitative research. Pearson.

Dahlberg, G., Moss, P. \& Pence, A. R. (1999). Beyond quality in early childhood education and care: Postmodern perspectives. Psychology Press.

Denscombe, M. (2007). The good research guide: For small-scale social research projects (3. utg.). Open University Press. 
Edwards, C. P. (1995). Democratic participation in a community of learners: Loris Malaguzzi's philosophy of education as relationship. https://digitalcommons.unl.edu/cgi/viewcontent.cgi?article=1014\&context=famconfacpub

Eneflo, E. (2014). Dokumentationens dilemman: Förskollärare samtalar om pedagogisk dokumentation [Doktorgradsavhandling, Umeå universitet]. DiVA. http://urn.kb.se/resolve?urn=urn:nbn:se:umu:diva-95481

Fairclough, N. (2008). Kritisk diskursanalyse: En tekstsamling. Hans Reitzels Forlag.

Fangen, K. (2010). Deltagende observasjon (2. utg.). Fagbokforlaget.

Fennefoss, A. T. \& Jansen, K. E. (2008). Småbarnspedagogikk og praksisfortellinger: Pedagogisk dokumentasjon gjennom tolkning og analyse. Fagbokforlaget.

Hewett, V. M. (2001). Examining the Reggio Emilia approach to early childhood education. Early Childhood Education fournal, 29(2), 95-100. https:/doi.org/10.1023/A:1012520828095

Jansen, K. E. (2013). På sporet av medvirkning og lering: De yngste barna og spenningsfeltet mellom det planlagte og det spontane. Fagbokforlaget.

Jansen, T. T. (2008). A arbeide mot det ukjente. Prosjektarbeid med barn i barnehagens faglige virksomhet. I T. Moser \& M. Pettersvold (Red.), En verden av muligheter-fagområdene i barnehagen (s. 175-197). Universitetsforlaget.

Kim, B. S. \& Darling, L. F. (2009). Monet, Malaguzzi, and the constructive conversations of preschoolers in a Reggio-inspired classroom. Early Childhood Education fournal, 37(2), 137-145.

Kilpatrick, S., Jones, T. \& Barrett, M. (2003). Defining learning communities. Centre for Research and Learning in Regional Australia.

Kjær, A. (2018). Barn og estetisk praksis: Sanser, varen og laring. Cappelen Damm Akademisk.

Kunnskapsdepartementet. (2017). Rammeplan for barnehagen. Forskrift om barnehagens rammeplan for innhold og oppgaver. https:/www.udir.no/laring-og-trivsel/rammeplan/

Lofland, J. \& Lofland, L. H. (1995). Analyzing social settings: A guide to qualitative observation and analysis. Wadsworth.

Malaguzzi, L. (1994) Your image of the child: Where teaching begins. Child Care Information Exchange, (3), 52-52.

Melvold, L. S. (2020). Prosjektarbeid. STYD, stolt og ydmyk. https://www.styd.no/prosjektarbeid-og-prosess

Pettersvold, M. (2012). Medvirkning, danning og demokrati i barnehagen. Barn, 2, $23-42$.

Postholm, M. B. (2010). Kvalitativ metode: En innføring med fokus på fenomenologi, etnografi og kasusstudier. Universitetsforlaget

Rinaldi, C. (2006). In dialogue with Reggio Emilia: Listening, researching and learning. Psychology Press.

Rogoff, B. (1994). Developing understanding of the idea of communities of learners. Mind, culture, and activity, 1(4), 209-229.

Schroeder-Yu, G. (2008). Documentation: Ideas and applications from the Reggio Emilia approach. Teaching Artist fournal, 6(2), 126-134. https://doi.org/10.1080/15411790801910735

Taguchi, H. (2000). Emancipation och motstånd: Dokumentation och kooperativa läroprocesser $i$ förskolan. HLS förlag.

Vakil, S., Freeman, R. \& Swim, T. J. (2003). The Reggio Emilia approach and inclusive early childhood programs. Early Childhood Education fournal, 30(3), 187-192. https://doi.org/10.1023/A:1022022107610

Åberg, A. \& Taguchi, H. L. (2006). Lyttende pedagogikk: Etikk og demokrati i pedagogisk arbeid. Universitetsforlaget. 